\title{
Diabetisk fotteam og insidens av amputasjoner
}

\author{
Det har vært en reduksjon i insidensen av amputasjoner hos pasienter med diabetes mellitus i Trondheim. \\ Selv om noe av denne reduksjonen kan skyldes redusert forekomst av aterosklerose i befolkningen generelt, \\ er vi av den oppfatning at virksomheten ved Diabetisk fotteam i byen har bidratt til færre amputasjoner hos \\ pasienter med diabetes mellitus.
}

I perioden 1995-2005 er insidensen av amputasjoner på leggen, gjennom kneet og på låret hos innbyggere i Trondheim med diabetes mellitus redusert med $40 \%(1,2)$. Vi tror noe av reduksjonen kan tilskrives etableringen av Diabetisk fotteam i 1996. I perioden 1996-2006 ble 779 pasienter med diabetes henvist til teamet, og til sammen ble det foretatt 5915 konsultasjoner (2).

\section{Tverrfaglig}

Teamet, som består av ortoped, fotterapeut, sykepleier, ortopediingeniør og gips- og ortosetekniker, holder en dag i uken til som en egen enhet ved ortopedisk poliklinikk. Organiseringen av teamet er flat, men ortopeden har det overordnede medisinske ansvaret, inkludert ansvaret for diagnosesetting. Sykepleier og fotterapeut har i stor grad ansvaret for undersøkelse av nye pasienter. I tillegg til å gi fotterapi tilpasser fotterapeuten forfotsortoser og avlastende filtortoser. Tilpasning av avlastende såler, andre ortoser og sko er ortopediingeniørens ansvar. Gips- og ortosetekniker har ansvaret for gipsing og tilpasning av avlastningsortoser.

Det er laget et undersøkelsesskjema der anamnese og klinisk status hos alle nye pasienter registreres. De får utlevert

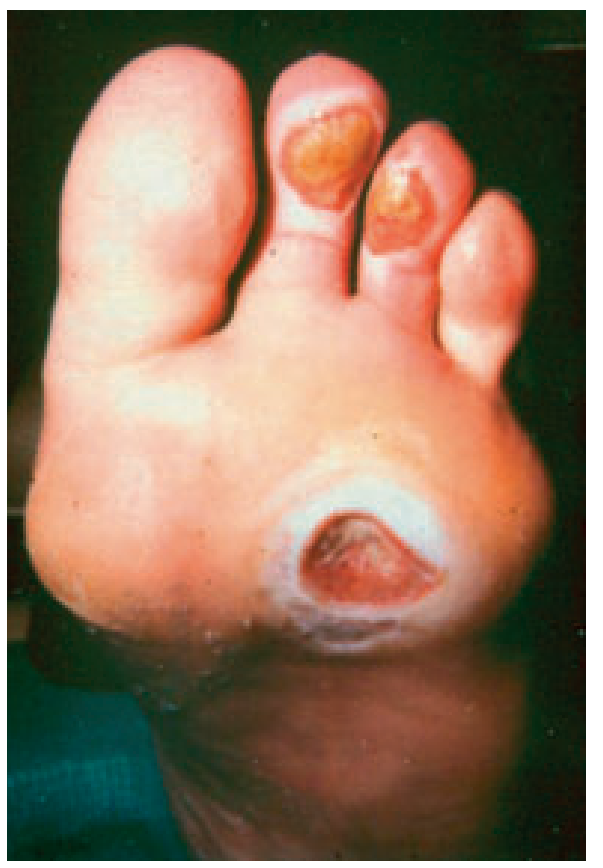

Diabetisk fotsår. Foto Eivind Witsø et informasjonsskriv om forebygging av fotsår. Poliklinikken er tilknyttet en sengepost, med mulighet for innleggelse som øyeblikkelig hjelp. Karfysiologisk utredning kan gjøres på kort varsel, og ved behov blir pasientene henvist til endokrinolog, hudlege og andre spesialister.

\section{Flere pasienter med diabetes - færre amputasjoner}

Diabetiske fotsår og diabetiske amputasjoner er i dag et betydelig helseproblem. Hver enkelt pasient med diabetes har opptil $25 \%$ risiko for å utvikle et diabetisk fotsår i løpet av livet, og bakgrunnen for diabetiske amputasjoner er i opptil $85 \%$ av tilfellene et diabetisk fotsår (3).

Det er anslått at i perioden 1997-2010 har antall mennesker i verden med diabetes mellitus økt fra 124 til 221 millioner. Spesielt forekomsten av diabetes type 2 synes å ha epidemisk karakter (4). I Europa er det $i$ flere land påvist en reduksjon i insidensen av diabetiske amputasjoner (5-9). De fleste tilskriver denne reduksjonen etableringen av diabetiske fotteam og økt vektlegging av problemet (10). Mangfoldiggjøring og spredning av internasjonale retningslinjer (11) blir også tillagt vekt. Disse retningslinjene er oversatt til norsk.

\section{Uutnyttet potensial}

Vi mener ortopedisk poliklinikk er et egnet sted for et diabetisk fotteam. På en slik poliklinikk er det kompetanse i bruk av avlastningsgips og i tilpasning av ortoser samt god tilgang på røntgenundersøkelser og rask vurdering ved mistanke om osteomyelitt og Charcot-forandringer. Fotterapeuten i teamet er viktig for forebygging av fotsår og kontroll av sårfrie pasienter. Vi har et stort forbruk av ortopediske hjelpemidler, og vår erfaring er at det ville være svært vanskelig å gjøre et godt forebyggende arbeid uten ortopediingeniør og fotterapeut.

Personer med type 2-diabetes utgjør hovedtyngden av pasientene. Vårt inntrykk er at disse har mer uttalte patologiske forandringer i beina og oftere fotsår ved første konsultasjon. Pasienter med type 1-diabetes synes å være bedre informert om hvordan de skal unngå fotsår. Dette kan skyldes aktiv informasjon fra Seksjon for endokrinologi, der de fleste med type 1-diabetes går fast til kontroll.

Skal insidensen av diabetiske amputasjoner reduseres ytterligere, må søkelyset rettes mot det tilbudet pasienter med type 2diabetes får. Konkret vil det si at primærhelsetjenesten og spesialisthelsetjenesten i større grad enn tidligere må samarbeide om disse. Vi har inntrykk av at det er et stort uutnyttet potensial for samarbeid med primærhelsetjenesten, i første rekke fastlegen. Svært mye av det forebyggende arbeidet burde kunne ivaretas av primærhelsetjenesten, mens behandlingen av diabetiske fotsår fortsatt må være en oppgave for spesialisthelsetjenesten. Hvert enkelt sykehus burde ha en klar oppfatning av hvilken avdeling som har ansvaret for diabetiske fotskader. Vi har erfart at det medfører store fordeler at en avdeling har et totalansvar, og at samme avdeling/seksjon har ansvaret for innlagte og polikliniske pasienter.

Vår konklusjon er derfor at en godt utbygd spesialisthelsetjeneste i samarbeid med primærhelsetjenesten er en nødvendig forutsetning for en fortsatt reduksjon i insidensen av diabetiske amputasjoner.

\section{Eivind Witsø}

eivind.witso@stolav.no

Ortopedisk avdeling

St. Olavs hospital

7006 Trondheim

og

Institutt for nevromedisin

Norges teknisk-naturvitenskapelige universitet

Arne Lium

Elin Langeng

Ortopedisk avdeling

St. Olavs hospital

\section{Anne Lutterloh}

Trøndelag Ortopediske Verksted

\section{Ann Lisbeth Grytdal}

Marit Ingeborg Skrinderhaug Kristiansen

Frode Bensvik

Tarjei Egeberg

Ortopedisk avdeling

St. Olavs hospital

\section{Stian Lydersen}

Institutt for kreftforskning og molekylær medisin Norges teknisk-naturvitenskapelige universitet

Oppgitte interessekonflikter: Ingen

\section{Litteratur}

1. Witsø $E$, Rønningen $H$. Lower limb amputations: registration of all lower limb amputations performed at the University Hospital of Trondheim Norway, 1994-1997. Prosthet Orthot Int 2001; 25: $181-5$

2. Wits $\varnothing$ E, Lium A, Lydersen S. Lower limb amputations in Trondheim. Acta Orthop 2010; 81: 737-44 Boulton AJ, Vileikyte L, Ragnarson-Tennvall G et al. The global burden of diabetic foot disease. Lancet 2005; 366: 1719-24. 
4. Aamos AF, McCarty DJ, Zimmet P. The rising global burden of diabetes and its complications: estimates and projections to the year 2010. Diabet Med 1997: 14 (suppl 5): S1-85.

5. Larsson J, Apelqvist J, Agardh CD et al. Decreasing incidence of major amputations in diabetic patients: a consequence of a multidisciplinary foot care team approach? Diabet Med 1995: 12: $770-6$

6. Morris AD, Mcalpine R, Steinke D et al. Diabetes and lower-limb amputation in the community. Diabetes Care 1998; 21: 738-43.

7. Holstein P, Ellitsgaard N, Olsen BB et al. Decreas- ing incidence of major amputations in people with diabetes. Diabetologia 2000; 43: 844-7.

8. van Houtum WH, Rauwerda JA, Ruwaard D et al Reduction in diabetes-related lower-extremity amputations in the Netherlands: $1991-2000$. Diabetes Care 2004; 27: 1042-6.

9. Trautner C, Haastert B, Mauckner P et al. Reduced incidence of lower-limb amputations in the diabetic population of a German city, 1990-2005. Diabetes Care 2007: 30: 2633 -7.

10. Apelqvist J, Bakker K, van Houtum WH et al. Practical guidelines on the management and prevention of the diabetic foot. Based upon the Consen- sus on the Diabetic Foot (2007). Prepared by the International Working Group on the Diabetic Foot Diabetes Metab Res Rev 2008; 24 (suppl 1): S181-7.

11. International Working Group on the Diabetic Foot. International consensus on the diabetic foot. Brussel: International Diabetes Federation, 1999.

Mottatt 10.12. 2010, første revisjon innsendt 2.3. 2011, godkjent 10.3. 2011. Medisinsk redaktør Siri Lunde.

\title{
Flere leger bør lære ledelse
}

\author{
Helsetjenesten er et meget komplisert system som krever ledelse. Vi mener det er behov for flere ledere \\ med medisinskfaglig bakgrunn, men det fordrer også lederopplæring av helsepersonell.
}

Å gå inn i en krevende lederstilling med kun legestudiet i bagasjen er i beste fall naivt, i verste fall kan en dyktig kliniker ødelegge karrieren og selvbildet. Faglig rettledning og instruksjon inngår i alle legers arbeid, uavhengig av om man ønsker å satse på en lederstilling i helsevesenet eller ikke. Den norske legeforening har for mange år siden innsett dette og krever en ukes obligatorisk kurs i administrasjon og ledelse for alle sykehusspesialiteter. Dette er «førstehjelpskurs» og gir et minstemål av innsikt $i$ ledelse.

\section{For mange «amatører»}

Legerollen er under press. Det er ikke bare det faglige arbeidspresset som øker, Overlegeforeningen er bekymret for at medi-

alle samfunnsgrupper, og vi har godt kvalifiserte helsearbeidere på alle nivåer. Vi har også ledere med medisinsk fagkunnskap i nøkkelstillinger i departement og direktorat, i regionale helseforetak, som sykehusdirektører og som ledere av divisjoner og avdelinger. Men flere leger bør skaffe seg formell kompetanse innen ledelse. Fortsatt er det for mange «amatører» som tar på seg for store oppgaver når de går inn i lederfunksjoner.

\section{Studentlegen}

For å kunne lede en medisinsk virksomhet kreves det kompetanse innen tre forskjellige områder: det faglige, det administrative og det politiske (3). Innsikt i den administrative og politiske verden lærer man i liten

\section{«Rapporten har flere anbefalinger, men den mest interessante fra et legesynspunkt er at de sykehusene som blir drevet best, har ledere med medisinskfaglig bakgrunn»}

sinskfaglig kompetanse ikke blir tilstrekkelig verdsatt av ledere i sykehus (1). Legene er bekymret fordi andre yrkesgrupper tar lederroller.

Konsulentfirmaet McKinsey har laget en omfattende rapport der de sammenlikner sykehusledelse i ulike land (2). Rapporten har flere anbefalinger, men den mest interessante fra et legesynspunkt er at de sykehusene som blir drevet best, har ledere med medisinskfaglig bakgrunn. En nærliggende forklaring er at dybdekunnskap om kjernevirksomheten er viktig for å kunne gå inn i lederfunksjoner på sykehus.

Vi burde ha alle muligheter for å skape velfungerende enheter med god ledelse i norsk helsevesen. Norge har god økonomi. Vi har et godt utbygd helsevesen som når grad på legestudiet. De medisinske fakultetene har nå innsett at ledelsesaspektet må inn i grunnutdanningen. Ved Universitetet i Bergen gis et ukeskurs med ledelsesemner på slutten av profesjonsstudiet i medisin. Universitetet i Oslo har siden 1986 tilbudt et ettårig masterkurs i helseledelse. Universitetet i Bergen har fra 2004 hatt et masterstudium for helsepersonell (4), hvor forfatterne er hhv. leder og styremedlem. Studiet består av tre grunnmoduler - helseledelse, kvalitetsforbedring og helseøkonomi - og en masteroppgave. Hver av grunnmodulene kan tas som en del av masterprogrammet, men de kan også tas for seg. Søkningen til studiet har vært god. I februar 2011 har til sammen 208 studenter gjennomført kurs i kvalitetsforbedring, 108 i helseøkonomi og 101 i helseledelse. 68 studenter har begynt på en masteroppgave. Av disse har 25 fullført per i dag. Søkningen har vært tverrfaglig, og vi ønsker flere leger som søkere til disse kursene. Etter vår mening er det viktig at leger kvalifiserer seg til lederstillinger i helsetjenesten, og en god utdanning er en solid kvalifikasjon.

\section{Aslak Aslaksen}

aslak.bjarne.aslaksen@helse-bergen.no Radiologisk avdeling

Haukeland universitetssykehus

5021 Bergen

og

Institutt for kirurgiske fag

Det medisinsk-odontologiske fakultet Universitetet i Bergen

\section{Kjell Haug}

Institutt for samfunnsmedisinske fag Det medisinsk-odontologiske fakultet Universitetet i Bergen

Oppgitte interessekonflikter: Ingen

\section{Litteratur}

1. Norsk overlegeforening. Legerollen kritiseres, endelig! www.legeforeningen.no/id/168309 (11.2.2011).

2. Dorgan S, Layton D, Bloom N et al. Management in healthcare: why good practice really matters. Rapport. London: McKinsey \& Company og the London School of Economics and Political Science, 2010. http://cep.lse.ac.uk/textonly/_new/research/ productivity/management/PDF/Management_ in Healthcare Report.pdf (19.3.2011).

3. Östergren K, Sahlin-Anderson K. Att leda sjukvård i omvandling. I: Östergren K, Sahlin-Anderson K. red. Att handtera skilda världar. Läkares chefskap i mötet mellan profession, politik og administrasjon. Stockholm: Landstingsförbundet, 1998: $11-29$

4. Universitetet i Bergen. Helseledelse, kvalitetsforbedring og helseøkonomi - erfaringsbasert master. www.uib.no/utdanning/evu/evutilbud/ helseledelse-kvalitetsforbedring-oghelseokonomi-erfaringsbasert-master (11.2.2011). 